\title{
Embedded Neopatrimonialism: Patriarchy and Democracy in Turkey
}

\section{Meral Ugur-Cinar*}

This article argues that patriarchal discourses can play a legitimizing role for the undemocratic elements of regimes. It focuses on neopatrimonial regimes in contemporary politics, which create impediments to democracy. Showing neopatrimonialism's link to patriarchal discourses, the study highlights the need to situate neopatrimonialism beyond its dominant contemporary usage as material exchange between the ruler and the ruled for political support. The Turkish case is analyzed to show how neopatrimonial acts of politicians are justified with a patriarchal discourse that is paternalistic and serves to reinforce personalistic rule, delegitimize opposition, and suppress pluralism.

\section{Introduction}

Yet another routine day in Turkish politics: "You cannot bring women and men to equal conditions," President Erdoğan stated, "it is against their nature." This statement, ironically made at the Women and Justice Summit (CNN Turk 2014B), echoes his previous statements (for similar statements see: Bianet 2014; Hogg and Pamuk 2014; Steinvorth 2012). Nor is Erdoğan alone. For example, one of the co-founders of the Justice and Development Party (Adalet ve Kalkınma Partisi-AKP), Bülent Arınç, has argued that a woman "should not laugh loudly in front of all the world and should preserve her decency at all times” (The Guardian 2014).

Such statements broadly represent the governing mentality in Turkish politics. According to the Gender Gap Index, Turkey ranks 130th out of 144 countries (World Economic Forum 2016). The literature on Turkey has shown how the status of women has been negatively impacted by the joint trends of conservatism and neoliberalism under AKP rule (Cosar and Yegenoglu, 2011), which exposes women to market insecurities and reinforces their domestic roles (Bugra 2014; Yılmaz Şener 2016).

Department of Political Science and Public Administration, Bilkent University, Ankara, Turkey

*meral.ugur@bilkent.edu.tr 
Does this patriarchal attitude only hurt women? Is it only the concern of people who care about women's rights? What kind of political leverage do rulers hope to derive from such statements? One of the main motivations of this article is to show that understanding these speeches solely in terms of malefemale relations misses the central dynamics of politics. As Eisenstein (1994, 31) has argued "as long as feminism, however it is defined, is thought of as 'dada' by leaders ... the struggle toward real democracy will be much more difficult. Totalitarianism and bureaucratic statism cannot be fully dismantled without addressing the unquestioned patriarchal privileging of men in the state, the economy, and the home." This statement points us in the right direction.

From a political vantage point, there is indeed an inseparable relationship between democracy and a more equal gender discourse. Yet is this only because women will have more rights in a more democratic society? The gender-regime nexus runs much deeper than this: the relationship is not unidirectional but goes both ways. This article will show that patriarchal political discourse contributes substantially to the undemocratic elements of regimes. To do so, it will focus on a particular regime type, neopatrimonial regimes.

\section{Democracy and Neopatrimonialism}

As the existing literature has shown, neopatrimonialism is inherently antidemocratic (Erdmann and Engel 2007, 114; Van de Walle 2007, 1). Neopatrimonialism is based on a system that ensures the stability of authoritarian regimes while at the same time undermining political participation and competition (Van de Walle 2007, 1). Neopatrimonialism is detrimental to liberal democracy, which rests on pluralism, checks and balances mechanisms, and rule of law, among other principles. Under neopatrimonial regimes, leaders are "largely above the law and not subject to the checks and balances that democratic executives face in mature democracies" (Van de Walle 2007, 1-2).

In an ideal democracy, different opinions can be voiced without incurring punishment and public services are provided according to institutionalized rules. However, there are leaders who would prefer that things go in accordance with their worldviews and that they allocate state resources as they wish. Patriarchal discourses can be used to justify such actions.

To unearth the multifaceted dynamics between gender discourse and regime type this article will show how patriarchal tropes play an enabling role in neopatrimonialism. In doing so, the study argues that neopatrimonialism involves more than a material exchange between the ruler and the ruled for political support. Rather neopatrimonialism needs to be located within its cultural and discursive context. In the next two sections, the article defines neopatrimonialism in the most general sense and then goes on to show why it involves more than its material dimensions. 


\section{Neopatrimonialism: History of a Concept}

The term neopatrimonialism was originally coined by Shmuel Eisenstadt (Gazibo 2012, 1). It arose out of the debates about whether it is possible to use patrimonialism to analyze contemporary societies. Eisenstadt thought that "patrimonialism" could be used to analyze current forms of political systems but that we needed to be aware of both similarities and differences between traditional and modern forms. According to Eisenstadt (1973), in modern societies, patrimonialism operated under more complex systems as the role of modern states was different. He therefore used the term neopatrimonialism to denote the operation of patrimonialism in modern societies (Eisenstadt 1973).

In contemporary political science literature, neopatrimonialism refers to the simultaneous operation of two Weberian ideal typical forms of domination: the patrimonial and the legal-rational (von Soest et al. 2011, 1309). Under pure patrimonialism, there is no distinction between the private and the public realms. All political relations are personal relations directly tied to the ruler. Under neopatrimonialism, formal rules do exist but they are not always observed as "the patrimonial penetrates the legal-rational system and twists its logic, functions, and effects" (Erdmann and Engel 2006, 18). Thus, we see a dual system in which modern bureaucracy exists side by side with elements of personalistic rule. As Erdmann and Engel (2007, 114) argue, "Public norms under neopatrimonialism are formal and rational, but their social practice is often personal and informal."

\section{Neopatrimonialism as Material Exchange and Beyond}

According to Weber (1978, 231), "patriarchalism is the situation where, within a group (household) which is usually organized on both an economic and a kinship basis, a particular individual governs who is designated by a definitive rule of inheritance." Patrimonialism came to existence when a (military and administrative) staff was introduced to the patriarchal system: "Patrimonialism ... tend[s] to arise whenever traditional domination develops an administration and a military force which are purely personal instruments of the master" (Weber 1978, 231). Patrimonialism therefore comes into existence as an extension of the ruler's authority (who is assumed, by default, to be male) in the household.

Tradition constitutes a crucial element of patrimonialism. Weber (1978, 232) describes patrimonial domination as "primarily traditional, even though it is exercised by virtue of the ruler's personal autonomy." By traditional authority Weber $(1978,215)$ means authority based "on an established belief in the sanctity of immemorial traditions and the legitimacy of those exercising authority under them."

Guenther Roth bases his concept on Weber's but he goes on to distinguish two types of patrimonialism traditionalist patrimonial regimes and modern 
personalist patrimonialism. The first is disappearing. With regard to the second, " $\mathrm{t}$ ] he type of patrimonialism is personal rulership on the basis of loyalties that do not require any belief in the ruler's unique personal qualification, but are inextricably linked to material incentives and rewards.” This materialist definition has dominated the neopatrimonialism literature, as reflected in the work of Guliyev and Hartlyn discussed below. As a result, neopatrimonialism came to be defined as a material exchange in which the ruled traded loyalty and political support for economic benefits provided by the rulers.

Thus, Guliyev $(2011,578)$ states that neopatrimonialism retains the arbitrariness of patrimonialism but not traditionalism. Under neopatrimonial administration, the state's coercive and administrative apparatuses are subordinated "to the individual executive on the basis of the 'loyalty and rewards' principle" (Guliyev 2011, 583). Similarly, Hartlyn claims that neopatrimonialism is no longer based on the traditional appeals to legitimate authority but rather on "the centralization of power in the hands of the ruler" and "a blurring of public and private purposes within the administration” (Hartlyn 1994, 94).

Pitcher et al., however, reject the depiction of neopatrimonialism as purely material. They believe that Weber was concerned with "the diverse ways in which the legitimate exercise of power could be culturally framed" and therefore "attempted to examine how the dominated understand, participate in, and even celebrate their domination" (Pitcher et al. 2009, 126-7). This article builds on this insight, bringing to the fore important, but often overlooked, aspects of the operation of neopatrimonialism. I will show that there are cultural frames that underlie neopatrimonial practices, which help to make them acceptable to at least parts of society. This study will argue that it is not possible to contest neopatrimonialism at the high political level without contesting the patriarchal codes that underpin it at the societal level.

To emphasize the discursive mechanisms through which neopatrimonialism is sustained is not to downplay its material basis. As our discussion of the Turkish case will also show, neopatrimonialism as a hybrid of personal patrimonial rule and legal-rational formal rule to a large extent does owe its existence to the material exchange built between the ruler and the ruled. However, material exchanges constitute necessary yet insufficient conditions for the reproduction of neopatrimonialism. To stress the economic side of the story is to neglect how regimes are legitimized in the eyes of the citizens. It is thus important to analyze the legitimizing and normalizing aspect of neopatrimonialism, which is built through patriarchy.

\section{Neopatrimonialism Embedded in its Patriarchal Discursive Framework}

The issue of legitimation cannot be ignored if we want to understand the functioning of regimes. As Pierson $(2011,17)$ suggests, issues of authority and 
legitimacy are central to the modern state as "no state can survive for very long exclusively through its power to coerce" and "a stable state requires that ... most of the people most of the time will accept its rule." It is not sufficient, or possible, to gain the loyalty of the majority of the population by either coercing them or buying them out with material resources. In addition to such practices, the state needs to put legitimating mechanisms in place.

In this context, patriarchy can play an important role. As a storyline learnt from childhood, normalized through socializing institutions and everyday practices, patriarchy creates an economy of politics. By providing shortcuts in the minds of citizens, politicians can rely on culturally embedded roles and obligations about family members. As fathers and husbands, state authorities are to be esteemed as natural sources of authority. At times as children and at times as wives, citizens are expected to follow the lead of the all-knowing leader who will bring happiness and fortune to the rest.

In her analysis of the relationship between nationalism and gender, McClintock (1995) argues that family tropes help to naturalize the hierarchy between members of the nation: "Since the subordination of woman to man and child to adult was deemed a natural fact, hierarchies within the nation could be depicted in familial terms to guarantee social difference as a category of nature" (McClintock 1995, 357-8). The same logic holds for democracy and subject formation. Since democracy is a regime in which the ruler and the ruled are deemed equal, patriarchal discourse helps to naturalize political hierarchies.

Thus, patriarchy needs to be understood as involving more than the inequality as between women and men. Patriarchy also involves other forms of subordination such as those caused by neopatrimonialism. Neopatrimonialism is a useful concept through which to analyze the effects of patriarchal discourses on regime times in general, and democracy in particular, since it is a regime type that effectively threatens democratic governance.

The article seeks to explain how patriarchy, with both its paternal and maledominant dimensions, endorses or even facilitates neopatrimonial rule. Thus far, this point has not been central to the neopatrimonialism literature. This neglect is surprising as both feminist and neopatrimonialism literatures have departed from similar points in their discussion of power. Weber, to whom the original study of patrimonialism is attributed, established a direct relationship between patrimonialism and patriarchy. According to Weber, patriarchy refers to "the social organization of power between men as exercised over women, children and slaves." Patrimonialism is a consequence of the extension of patriarchy beyond the household through the assignment of land and equipment to sons of the house or other dependents (Sydie 1987, 62 and 64).

Weber $(1978,1006-7)$ did not problematize the subordination of women and children under patriarchal domination as the following quote clearly shows:

The woman is dependent because of the normal superiority of the physical and intellectual energies of the male, and the child because of 
his objective helplessness, the grown-up because of habituation, the persistent influence of education and the effect of firmly rooted memories from childhood and adolescence, and the servant because from childhood on the facts of life have taught him that he lacks protection outside the master's power sphere and that he must submit to him to gain that protection.

Feminists have accordingly criticized Weber's approach to patriarchy (Adams 2005a; Sydie 1987). I argue that we also need to expose the socially constructed nature of the patriarchal basis of (neo)patrimonialism.

The feminist literature can be of significant help in developing an adequate conceptualization of neopatrimonialism. At the same time, as Adams (2005b, 33) maintains, feminist theory "has failed to address and incorporate sociological theories of state formation." It is important, however, to probe how the gendered discourse of the state and the regime serve as legitimation tools for state officials.

Two scholars have analyzed the link between gender tropes and state legitimation. One is Schatzberg, who in his studies of African regimes has pointed at how gendered understandings of the state and society have influenced citizens' views of the state. Schatzberg $(1993,446)$ emphasizes the importance of examining political language, including metaphors and other images used to understand the cultural components of political legitimacy. These cultural components consist of what Schatzberg calls "moral matrices." These matrices "form a culturally rooted template against which people come to understand the political legitimacy, or 'thinkability,' of institutions, ideas, policies, and procedures" (Schatzberg 2001, 1). The moral matrix is an "implicit cultural and cognitive template encompassing the sum of tacit understandings of how key political concepts, such as power, are intuitively and implicitly defined; of what constitute the parameters of the political kingdom; and of how individuals comprehend the forces of political causality (Schatzberg 2001, 35).

According to Schatzberg, the first principle upon which political legitimacy in much of sub-Saharan Africa is based is that "the tacit normative idea that government stands in the same relationship to its citizens as a father does to his children. There is a substratum of belief which views paternal authority as legitimate as long as the implicit understanding of rights and duties contained in the moral matrix is not violated." Paternal and familial metaphors especially revolve around "presidential fathers" and "the nation as family and as growing child” (Schatzberg 1993, 455).

Thomas also provides sharp insights into the relationship between familial discourse and political legitimacy. Thomas $(2011,4)$ begins with the finding that "idealized relationships among families and between families and other institutions provide important symbolic and discursive resources for political actors." Political leaders and mobilized citizens use such familial beliefs "to provide the language, metaphors, symbols, and images that framed their 
political appeals, justified their political actions, and made sense of larger political events" (Thomas 2011, 5).

Given the crucial role of gender in our discussion of states and regimes, we can benefit from radical feminist arguments that show how patriarchy is at the core of political domination. Yet two additions need to be made. The first concerns the need to recognize that gender inequality and patriarchy not only target women but also lead to undemocratic and unequal political practices. Second we need to emphasize that male dominance is only part of the story. While radical feminism was successful at pointing out the political power asymmetries introduced by patriarchy, it has generally confined its understanding of patriarchy to male domination and, in fact, has defined patriarchy as such (Arat 1989, 19; Bracke 2014; Thompson 2001, 60; Walby 1990, 19-20). Radical feminists have recognized that men's domination over women, in the form of conjugal rights has preceded their domination over their children, even when thought of in terms of simple chronology (Pateman 1988, 3). As the person primarily to be credited for bringing patriarchy to the forefront of feminist studies, Kate Millett (2000[1970], 25) recognized the dual nature of patriarchy: "male shall dominate female, and elder male shall dominate younger." Yet, she too, focused on the former at the expense of the latter due to the "birthright priority whereby males rule females" (Millett 2000[1970], 25).

Radical feminism thus provides a good starting point. But by focusing on the "male domination" aspect, feminism excludes the paternalistic aspect of patriarchy, which is still very prominent in countries such as Turkey. Thus, while Pateman notes that the social contract theories formulate a political community of horizontal brotherhood at the expense of female subordination, the Turkish case demonstrates that young Turkish males are also far from being included as equal members of the political community. ${ }^{1}$

As the Turkish case reveals, paternalism constitutes an essential element of patriarchy and it is vital to understanding the patriarchyneopatrimonialism linkage. Hence, we need to extend the definition of patriarchy to highlight the place of paternalism, that is the dual use of a paternal political discourse to at once denote elder dominance of the youth and the state dominance of its citizens. Only when we take into account this dual nature of patriarchy can we fully grasp its power in the political arena. The intertwined characteristics of patriarchy as male-domination and as the rule of the elder are key ingredients of the authoritarian blend in Turkey and other parts of the world. ${ }^{2}$

\section{Neopatrimonialism and Patriarchy in Turkey}

The Turkish political system includes all elements of a neopatrimonial regime. In their seminal work on neopatrimonialism, Bratton and van de Walle maintain that "the characteristic feature of neopatrimonialism is the 
incorporation of patrimonial logic into bureaucratic institutions." The chief executive and the inner circle of the chief executive "undermine the nominally modern state administration by using it for systematic patronage and clientelistic practices in order to maintain political order" (Bratton and van de Walle 1997, 62). Thus, the Turkish case can be defined as neopatrimonial as even though the leader has a lot of room for maneuver, there also exists an elaborate network of political and bureaucratic institutions, which give the regime a legal-rational appearance.

Bratton and van de Walle identify three core elements of neopatrimonial regimes: presidentialism, systematic clientelism, and the use of state resources for political legitimation. Presidentialism is defined as "the systematic concentration of political power in the hands of one individual, who resists delegating all but the most trivial decision-making tasks" (Bratton and van de Walle 1997, 63). Systematic clientelism involves awarding personal favors to secure political support and obedience. Such favors include public sector jobs as well as distribution of public resources through licenses, contracts, and projects (Bratton and van de Walle 1997, 65). Since neopatrimonial leaders make little distinction between public and private coffers, they use state resources for their political needs (Bratton and van de Walle 1997, 66).

In Turkey, the leader has increasingly occupied the role of the main actor in politics. The most powerful figure was originally the prime minister but after each military intervention, presidents gained more power and in the controversial referendum held in April 2017, Turkey formally switched to a presidential regime.

There has long been a tension between neopatrimonialism and democracy in Turkey. The Turkish state has long been the dominant actor in Turkish politics and the rule of law was always problematic. ${ }^{3}$ Yet apart from the period of single-party rule that lasted until 1950, politicians have had to share power with the undemocratic military establishment and/or with their coalition partners. The nature of coalition governments helped to curb personalism as no party had full control over state resources. Nevertheless, with the fading of military power and with AKP's consolidation of its single-party power, neopatrimonialism has become a dominant characteristic of the Turkish political system.

With regard to the systematic concentration of personalistic power, the main political figure is the former prime minister, now president, Erdoğan. Erdogan is very open about the personalistic aspects of his rule as his use of possessive adjectives while talking about state officials as well as citizens reveals. The following represent some examples of this: "my citizens," "my Kurdish brothers," "my Minister of Foreign Affairs," "my charge d'affaires," "my ministers," "my women's branches," "my head of the youth branches," "my Minister of Interior," "my Minister of Justice," "my chief of the general staff" (Basaran 2012; T242013). When the editor-in-chief of the daily Habertürk acknowledged regular phone calls from government officials and 
publicly claimed to be under constant political pressure (Hürriyet Daily News 2014), Erdoğan responded that he or his friends make such calls to the media whenever they feel it is necessary.

The second component of neopatrimonialism, systematic clientelism, is also widely observed in Turkey. Systematic clientelism is especially visible in the media and in the business sector. Media companies and business corporations loyal to the current government are rewarded for their support with government contracts and concessions (Çarkoğlu and Yavuz 2010, 618; Silverman 2014) whereas media sources critical of government policies face punishments such as tax investigations or pressure to fire journalists. One prominent example is the Doğan Media case. Following criticism of the government and the coverage of a scandal involving an Islamist charity and some AKP officials in 2009, Doğan Media, the largest media conglomerate in Turkey, faced a total of $\$ 3.5$ billion in tax charges by the Ministry of Finance, which nearly equaled the total value of Doğan's assets (Yesil 2014, 165; see also Yilmaz 2013).

A similar pattern can be discerned in the case of the Koç Company. Like Doğan, Koç has also faced direct economic punishment after being personally targeted in Erdoğan's speeches. During the summer 2013 Gezi protests, the Divan Hotel owned by the Koç Company opened its doors to demonstrators wounded by pepper gas and police brutality. Erdoğan, who accused the hotel of harboring criminals, stated the following: "We know those who cooperate with terrorists and accommodate them in their hotels. We will settle accounts on this" (Gursel 2014). Subsequently, tax inspectors and police raided Tupras, Koç's refinery subsidiary. The government canceled a $€ 1.1$ billion tender for Koç to build Turkey's first warship (Dombey 2013). Record-level tax penalties were issued against the Koç Group. On 13 December, Koç's Yapı ve Kredi Bankası was fined \$56 million, followed on 17 December by Tofaş (Fiat), the largest automotive company in the country, with $\$ 29.3$ million. Tupras was penalized with \$179.1 million (Gursel 2014). Erdoğan openly used his stickcarrot mechanism. Upon hearing that some companies were canceling their spots at the planned shopping mall which was going to replace the Gezi Park had it been demolished, Erdoğan (Bianet 2013a) said "If any company is cancelling their agreements as a result of the [Gezi] events, they will pay a hefty price for it ... These companies have always received a lot of support from us thus far."

Opposition is hard to maintain in this atmosphere. Many journalists have in fact been fired from their jobs (television and/or newspaper) and have been put to jail for criticizing Erdoğan's rule. Overall, journalistic freedom in Turkey has declined under the AKP government. (For more on press censorship, firings, and resignations see Yesil 2014. See also Corke et al. 2014.) As of 2017, Turkey was categorized as "not free" based on its press freedom by the Freedom House (Freedom of the Press 2017: Turkey Profile). Reporters without Borders (2017) list Turkey 155th out of 180 in terms of press freedom. 
The classification of Turkey as neopatrimonial may strike some as surprising as countries described as neopatrimonial normally have the following common characteristics: colonial legacies, weak states, unfair elections or no elections at all (Compagnon, 2012, 54; Erdmann and Engel 2006, 19-20; Erdmann and Engel 2007, 114; Mentan 2004, 223). Erdmann and Engel (2006, 19-20), for example, explain the colonial roots of African neopatrimonialism by noting that, historically, the legal-rational sphere in the colonies was confined to the center of power at the colonial capital. It thus reached only the population of European descent and some small immigrant groups. The rest of the society was under indirect rule, governed by intermediary authority, which constituted the realm of patrimonial rule, of kings, chiefs, and elders. After World War II, colonial powers briefly made an effort "to build up a legal rational bureaucracy that included ... to some degree Africans." This period was too short and the resources too scarce to establish "a major and lasting move to an 'autonomous' legal-rational bureaucratic culture." Thus, after independence, "with the Africanisation of the bureaucracy and the establishment of authoritarian rule, the bureaucracy was extended and at the same time challenged and invaded from above and below by informal relationships" (Erdmann and Engel 2006, 19).

The case for neopatrimonialism in Turkey thus seems unlikely. Turkey has no colonial legacy, it is categorized as a strong state, its bureaucratic institutions are capable of operating. Further, it used to have a long parliamentary tradition, and elections were mostly known to be fair. Why then have neopatrimonial tendencies become dominant in contemporary Turkey?

The existing literature on patrimonialism and neopatrimonialism in Turkey focuses on the sultanistic legacy of Ottoman rule (Inalcik 1992). The patrimonial nature of Ottoman rule has meant that pluralism and civil society have been approached with skepticism in Turkish politics (Mardin 1969). Research on the history of contemporary Turkey has mostly focused on the material bases of exchange between the ruler and the ruled based on the clientelistic relationship built between them (Sayar1 2011).

The clientelistic relationship existed mainly between local notables, CHP's (Republican People's Party-Cumhuriyet Halk Partisi) grassroot organizations, and state officials during the single party era (1923-1946) (Sayar1 2014). The Democrat Party, which came to power after the single-party period, incorporated the rural population in a clientelistic network and established patronage-induced private entrepreneurship, which then became permanent features of center-right politics in Turkey (Sunar 1990). As Sayarı (2014, 659) argues, the politicization of existing vertical networks of clientelistic ties during the early years of the multi-party period are in marked contrast with horizontal solidarities based on common class or group affiliations that constitute the core of voter alignment in Western Europe. Recent research on Turkish politics has shifted the focus from rural to urban forms of clientelism due to the increasing levels of rural to urban migration (Sayarı 2014, 660). Such 
networks have become very extensive and elaborate in the era of the AKP (Sayar1 2014, 664-5).

Konak and Dönmez $(2015,66-7)$ have recently noted that in addition to the clientelistic basis of Turkish politics, the AKP has utilized majoritarian electoral authoritarianism and the formation of a security oriented police state.

The supporters of neopatrimonial policies are not limited to those who reap material benefits of such policies. Yet as the Turkish case suggests, politicians might in fact be very open about their neopatrimonial activities and still have wide public support without such neopatrimonial policies necessarily benefiting society at large. To understand this dynamic, we need to bring in patriarchal discourses and cultural frames, which complement material based explanations of neopatrimonialism.

\section{In the Service of Neopatrimonialism: Patriarchal Discourse in Action}

The Turkish case illustrates how the paternalistic aspect of patriarchy operates in tandem with male domination. The language used and the ease with which analogies can be made between the state and the family and the ruler and the father is striking. The AKP government, led by Erdoğan, routinely makes statements that attempt to control the lives of women. Erdoğan has urged women to give birth to at least three children, has called birth control treason, and has made stark comments against cesarean section and abortion (Radikal 2014; The Independent 2012). Such acts are seen as treason because they lead to lower population growth. Through such statements he positions himself as the one who knows what is best for the nation, reinforcing his status as the personalistic head of a neopatrimonial rule.

In addition to seeing women as subordinate to men, the political leadership identifies women as "their" mothers, daughters, and sisters (Ntvmsnbc 2013) rather than as women or citizens.

Erdoğan, instead of acknowledging young women as women, insists on calling them his daughters. This applies mostly to women with headscarves whom he frequently calls "benim başörtülü kızlarım (my headscarved daughters)" (Hürriyet 2013). It did not make a difference that most of such women were middle aged.

The treatment of women within this patriarchal framework is dependent on where women stand in the neopatrimonial spectrum, i.e. their relationship and attitude toward the leader. This differential treatment, in which "only the deserving will be protected," is captured by Kandiyoti's (2014) analysis of two episodes in Turkey's recent history. The first concerns the alleged attack on a veiled woman in front of Istanbul's Kabataş dock at the height of the Gezi protests. Although CCTV footage has later challenged this story, "this incident 
had the PM [Erdoğan] fuming over the affront to 'our sister' that demonstrated the violent, barbaric and anti-religious disposition of the protesters." Kandiyoti contrasts this incident with an earlier episode concerning a female demonstrator, who, during a protest in Ankara in June 2011, climbed on a tank and was savagely beaten by the police. This time the former PM belittled the incident, "... casting aspersions on her virginity he left his listeners in no doubt that he thought her of small virtue, as would be expected from her unseemly, unfeminine behavior. The message could not be clearer: only the deserving (our sisters) are worthy of protection, the rest, and especially women with the audacity to break the norms of modesty and protest in public put themselves in jeopardy."

In addition to the omnipresent male domination, we also need to scrutinize the strong paternalistic tones of Turkish patriarchalism. The Gezi protests became an epitome of the state's patriarchal attitude toward its citizens. During the protests, Erdoğan (Bianet 2013b) addressed the "young kids" [genç yavrularımız] in Gezi Park: "Please do not fall prey to the games of illegal organizations. We have maintained our patience but we are reaching its end. I am warning you for the last time. I am saying 'mothers, fathers take care of your children [yavrularınıza sahip çıkın]'." In the aftermath of Gezi, Erdoğan maintained that the "interest lobby" and the enemies of Turkey profited by the protests whereas "young people became victims of this plot." Thus, undermining the agency of the protestors, Erdoğan (CNN Turk 2014A) argued that the youth protesting in Gezi Park were manipulated by those who wanted to harm Turkey's international image and its economy.

The description of the Gezi protestors as youth is questionable. According to Konda's Gezi survey (Konda 2014, 8), the average age of the respondents was 28. Konda has also observed that the protesters were representative of Turkish society since the average age is 30.3 in Turkey (30.1 in Istanbul). Only $22 \%$ of the Gezi Park protesters were 20 years old or younger. The majority of the protesters did not comprise high school students or college students in their freshman or sophomore year (June 5, 2014, 9).

Schatzberg $(2001,25)$ suggests that the depiction of the father chief has important consequences for the political opposition. If the presidents are the "fathers" of their respective national "family," their people are reduced to the role of his children. These regimes can present, therefore, any political protest as the work of "ungrateful" or "misguided" or "wayward" children. They are all brothers and sisters, and like siblings who squabble over inconsequential matters, citizens do also. Important political questions may thus be presented as the petty sibling rivalries of those lacking in maturity. And the "father" must occasionally "discipline" naughty and immature children for their own good. The political consequences of framing the political discussion in this manner are important as the metaphors contribute to an implicit "infantilization" of the population. 
Thus, by depicting the protesters as children, Erdoğan and the AKP government attempted to deny the protesting citizens agency and to delegitimize their claims for a more democratic and pluralistic society. Thus state paternalism explicitly portrayed the protestors as younger citizens even though most of them were well above 18, the age one is legally considered an adult and eligible to vote in Turkey.

State paternalism does not stop with young people but is expanded to all citizens. In a very striking statement, more recently Erdoğan likened his job to that of a shepherd: "The one who does not understand the philosophy and psychology of being a shepherd, cannot rule people. I am a shepherd, too." (Sputniknews 2016).

Through paternalism, the state is seen as the source of wisdom, protection, and growth for its citizens as bans on alcohol in Turkey and Erdoğan's call on married couples to have at least three children have shown (Daloglu 2013; Hürriyet Daily News 2013; The Economist 2013) Paternalism's links to neopatrimonialism are commonplace in Turkish society. The earlier example of Erdoğan's relationship with the media is just once such illustration. As he said at the time, "When such insults are made, I or my friends call to tell [newspaper executives] ... I don't know if it is wrong [telling them] this. But we have to teach such things ... [emphasis added]" (Hürriyet Daily News 2014). Here the all-knowing leader teaches the media how to conduct its job.

Another example is Erdoğan's reaction to smoking. Whenever he sees someone with a pack of cigarettes, he confiscates the cigarettes, asks the person to put on the package the date, his signature and a sentence that states that the person has quit. On one occasion, Erdoğan got furious when a group of people saw him yet did not put out their cigarettes. He called these people shameless because they continued to smoke even though he told them otherwise (Haberturk 2014). What is at stake here is not only a fight against a noxious substance. It is also an attempt to make everyone obey the lifestyle he deems fit for society.

The private and public roles of the leader are also conflated and merged with familial roles. Erdoğan's relationship to a group of celebrities in Turkey reflects this. For example, a well-known TV star, Murat Yıldırım, depicted Erdoğan as godfather (manevi baba). Thus, Erdoğan was the one who asked Yildırım's would-be wife's father for her hand on behalf of him (Yeni 2017). In a similar vein, a Turkish singer Alisan also stated that he kept his promise to the president to marry someone within 6 months and that his biggest dream is that the president would attend his wedding (Internetmedya 2017).

Overall, we can discern a pattern in which there is a deliberate conflation of personality and state. This happens in two intertwined steps: First, we observe the equation of the family with the state. Second, we see the reflection of norms and expectations that apply to the family, on to the state. Through these two steps everyday neopatrimonialism is normalized in Turkey. In other words, the familial feeds the neopatrimonial. 
In addition to the discursive practices, policies also reinforce the appeal of the neopatrimonial regime. Social benefits have been tied much more openly to the AKP rule and to Erdoğan in particular. As a result, instead of seeing such benefits as a citizenship rights, some parts of society have come to see them as favors provided by the president. It is common to see individuals thank the president in the news for helping them out on a health matter or other social issue. Thus, the political leadership has become popular especially for sectors of the society that did not benefit extensively from the formal social security network (Bugra and Candas 2011). Designating women as the recipients as primary caregivers has furthered this patriarchal trend (Y1lmaz Şener 2016). It is no surprise that the party's strongest support lies with the less educated, poor and female voters who are confined to their homes and looking to the AKP and Erdoğan as sources of social security (Çarkoğlu and Aytaç 2015; Cinar 2016; Gidengil and Karakoç 2016). Thus, one could argue that the neopatrimonial trend is reinforced by material as well as discursive practices.

\section{Conclusion}

This article has shown that to understand how even in the age of democracy, modern bureaucracy and legal-rationality, regimes can justify neopatrimonial and authoritarian traits, we need to look at how gender operates as a regulating discourse. The gendered discourse enables the state to legitimately balance the egalitarian components of democracy with the hierarchical aspirations of its authority. Patriarchy both reduces women and (most) men to a position of submissiveness in which personal favors replace legal entitlements of citizens.

I have tried to show in this article that patriarchal discourses are at the heart of politics. They have an impact on sustaining a regime type and projecting certain types of authority. By naturalizing hierarchies between the ruler and the ruled and by dismissing pluralism and the value of differing opinions they are detrimental to democracy. They can subvert the authority of rule of law and established institutions and play in the hands of the personalistic authority of the ruler as the case of neopatrimonialism illustrates. As the all-knowing patriarch who knows what is best, the neopatrimonial leader becomes the bearer of national interest and the embodiment of the nation. Institutions still exist, but they are auxiliary to the rule of the leader. They can be bent according to his will and they can be constantly undermined in a populist fashion. In this system, the people are depicted as in need of help, guidance and protection. They are infantilized and seen as naïve and vulnerable at best, being open to manipulation at worst.

Tradition and culture of course are not natural, holistic or deterministic. As the nationalism literature has shown us (Hobsbawm and Ranger 1983), political entrepreneurs borrow selectively from a country's cultural and historical 
repertoire and even invent new traditions. In other words, patriarchy is reproduced strategically and dynamically. Moreover, as alternative formulations of especially feminists have shown, countries are not bounded by hegemonic formulations. Yet the socialization of citizens within patriarchal families, in schools, and through the media gives strength to some framings of culture. Such socialization also enables some analogies between the state and the family more than others.

Although patriarchal stories have a wide range, they are not omnipotent. There is still room to challenge such stories and the undemocratic political regimes that accompany them. As the widespread use of subversive slogans on gender and patriarchy at the Gezi protests have shown, the opposition can challenge patriarchal authority at its very core. At Gezi, using patriarchal tropes in a subversive manner the protesters tried to unsettle the patriarchal premises of authority by severing the patriarchal ties that bound them to the state.

As Gramsci (1971) argued, the strongest form of compliance mechanism is the hegemonic form. It is so automatic, almost second nature, that states do not need to use any additional force or persuasion mechanisms. Consequently, paying attention to and problematizing gender hegemony is likely to open liberating possibilities that are too important to be neglected.

\section{Notes}

Meral Ugur-Cinar received her PhD in Political Science from the University of Pennsylvania in 2012. She was a Mellon Interdisciplinary Postdoctoral Fellow at the New School for Social Research in 2012-2013. Her research interests include political institutions, democracy, citizenship, collective memory, social movements, and gender. Her articles appeared in PS: Political Science \& Politics, Political Studies, Political Quarterly, Middle Eastern Studies, Mediterranean Studies, and Turkish Studies. A chapter she coauthored with Rogers Smith can be found in Political Peoplehood: The Roles of Values, Interests and Identities (Chicago University Press). Her book titled Collective Memory and National Membership: Identity and Citizenship Models in Turkey and Austria is published by Palgrave. Meral is currently Assistant Professor at Bilkent University, Ankara, Turkey.

1. Pateman $(1988,4)$ acknowledges that her use of patriarchy is geographically bound and historically contextualized.

2. Among other cases, e.g. African cases, see, for example Schatzberg (1993). On paternal seniority in Indonesia, see Nilan and Demartoto (2012).

3. In Turkey, rule of law was either put in jeopardy by leaders who wanted to rule by decree (such as Adnan Menderes and Turgut Özal) and the military, who assumed the duty to intervene in politics and changed the rules of the game many times. On Menderes' violation of rule of law, see Özbudun (2000, 31). On Özal's subversion of the rule of law, see, for example, Öniş (2004). 


\section{References}

Adams, Julia. 2005a. The rule of the father: patriarchy and patrimonialism in early modern Europe. In Max Weber's Economy and Society: A critical companion, ed. C. Camic, P. S. Gorski and D. M. Trubek, 237-66. Stanford, CA: Stanford University Press.

2005b. The familial state: Ruling families and merchant capitalism in early modern Europe. Ithaca, NY: Cornell University Press.

Arat, Yeşim. 1989. The patriarchal paradox: Women politicians in Turkey. London: Associated University Presses Inc.

Basaran, Ezgi. 2012. Basbakanin iyelik ekleri ve zararlari [The prime minister's possessive pronouns and their dangers]. Radikal. http://www.radikal.com.tr/yazarlar/ezgi_ basaran/basbakanin_iyelik_ekleri_ve_zararlari-1096470, 7 August.

Bianet. 2013a. Erdoğan'ın Gezi eylemi yorumu: Tencere tava hep aynı hava. http://bia net.org/bianet/siyaset/147162-erdogan-in-gezi-eylemi-yorumu-tencere-tava-hepayni-hava, 3 June.

Bianet. 2013b. Başbakan Erdoğan: 'Avrupa Parlamentosu'nun kararını tanımıyorum.' http://www.bianet.org/bianet/siyaset/147529-avrupa-parlamentosu-nun-kararinitanimiyorum, 13 June.

Bianet. 2014. Erdoğan 'fitrat sözlerim çarpıtıldı' dedi, aynı cümleleri tekrarladı [Erdoğan said that his words were distorted and reiterated the same sentences]. http://bianet.org/bianet/kadin/160284-erdogan-fitrat-sozlerim-carpitildi-dedi-aynicumleleri-tekrarladi, 26 November.

Bracke, Maud Anne. 2014. Women and the reinvention of the political: Feminism in Italy, 1968-1983. New York: Routledge.

Bratton, Michael and Nicolas van de Walle. 1997. Democratic experiments in Africa: Regime transition in comparative perspective. Cambridge: Cambridge University Press.

Bugra, Ayse. 2014. Revisiting the Wollstonecraft dilemma in the context of conservative liberalism: The case of female employment in Turkey. Social Politics: International Studies in Gender, State and Society 21(1): 148-66.

Bugra, Ayşe and Aysen Candas. 2011. Change and continuity under an eclectic social security regime: The case of Turkey, Middle Eastern Studies 47(3): 515-28.

Cinar, Kursat. 2016. Local determinants of an emerging electoral hegemony: The case of Justice and Development Party (AKP) in Turkey, Democratization 23(7): 1216-35.

CNN Turk. 2014A. Erdoğan Gezi Parkı çağrısı için çok sert konuştu [Erdoğan spoke harshly about the Gezi Park call], http://www.cnnturk.com/haber/turkiye/erdogangezi-parki-cagrisi-icin-cok-sert-konustu, 30 May.

CNN Turk. 2014B. Erdoğan: Kadın ve erkeğin eşit olması fitrata ters [Erdoğan: Male-female equality is against nature]. http://www.cnnturk.com/haber/turkiye/ erdogan-kadin-ve-erkegin-esit-olmasi-fitrata-ters, 24 November.

Compagnon, D. 2012. The model of the political entrepreneur. In Neopatrimonialism in Africa and beyond, ed. D. Bach and M. Gazibo, 46-57. Abingdon: Routledge.

Corke, Susan et al. 2014. A Freedom House special report, democracy in crisis: Corruption, media, and power in Turkey, http://www.freedomhouse.org/sites/de fault/files/Turkey\%20Report\%20-\%20Feb\%203,\%202014.pdf, 3 February. 
Cosar, Simten and Metin Yegenoglu. 2011. New grounds for patriarchy in Turkey? Gender policy in the age of AKP. South European Society and Politics 16 (4): 555-73.

Çarkoğlu, Ali and Gözde Yavuz. 2010. Press-party parallelism in Turkey: An individual level interpretation. Turkish Studies 11 (4): 613-24.

Çarkoğlu, Ali and S. Erdem Aytaç. 2015. Who gets targeted for vote-buying? Evidence from an augmented list experiment in Turkey. European Political Science Review 7 (4): 547-66.

Daloglu, Tulin. 2013. Erdogan insists on demanding three children. http://www.al-mon itor.com/pulse/tr/originals/2013/08/erdogan-asks-turks-to-have-three-children. html, 13 August.

Daniel. 2013. Turkish businesses targeted after Erdoğan comments. http://www.ft.com/ intl/cms/s/0/4093e50a-1c8b-11e3-a8a3-00144feab7de.html\#axzz3BR799Z4W, 13 September.

Eisenstadt, Shmuel N. 1973. Traditional patrimonialism and modern neopatrimonialism. Beverly Hills, CA: Sage Publications.

Eisenstein, Zillah R. 1994. The color of gender: Reimaging democracy. Berkeley, CA: University of California Press.

Erdmann, Gero and Ulf Engel. 2006. Neopatrimonialism revisited-beyond a catch-all concept. Giga Working paper 16.

- 2007. Neopatrimonialism reconsidered: Critical review and elaboration of an elusive concept. Commonwealth \& Comparative Politics 45(1): 95-119.

Freedom of the Press 2017: Turkey profile. 2017. https://freedomhouse.org/report/free dom-press/2017/turkey.

Gazibo, Mamoudou. 2012. Introduction. In Neopatrimonialism in Africa and beyond, ed. D. Bach and M. Gazibo, 1-6. Abingdon: Routledge.

Gidengil, Elisabeth, and Ekrem Karakoç. 2016. Which matters more in the electoral success of Islamist (successor) parties-religion or performance? The Turkish case. Party Politics 22 (3): 325-38.

Gramsci, Antonio. 1971. Selections from the prison notebooks. New York: International Publishers.

Guliyev, Farid. 2011. Personal rule, neopatrimonialism, and regime typologies: Integrating Dahlian and Weberian approaches to regime studies. Democratization 18(3): 575-601.

Gursel, Kadri. 2014. Erdoğan accuses TUSIAD chairman of treason. http://www.almonitor.com/pulse/originals/2014/01/erdogan-tusiad-treason-turkey-business-taxpolitics.html\#\#ixzz3BW7rd0Ex, 27 January.

Haberturk. 2014. Cumhurbaşkanı Erdoğan'ı kızdıran olay! http://www.haberturk.com/ gundem/haber/1005567-cumhurbaskani-erdogani-kizdiran-olay, 2 November.

Hartlyn, Jonathan. 1994. Crisis-ridden elections (again) in the Dominican Republic: Neopatrimonialism, presidentialism, and weak electoral oversight. Journal of Interamerican Studies and World Affairs 36 (4): 91-144.

Hobsbawm, Eric and Terence Ranger, ed. 1983. The invention of tradition. Cambridge: Cambridge University Press.

Hogg, Jonny and Hümeyra Pamuk. 2014. Fight against domestic violence stalls in 'patriarchal' Turkey. Hurriyet Daily News. http://www.hurriyetdailynews.com/fightagainst-domestic-violence-stalls-in-patriarchal-turkey.aspx?pageID $=517 \& \mathrm{nID}=69$ $455 \&$ NewsCatID=339, 22 July. 
Hürriyet. 2012. Dindar bir gençlik yetiştirmek istiyoruz [We want to raise a pious youth.] http://www.hurriyet.com.tr/gundem/19819295.asp, 1 February.

Hürriyet. 2013. Başbakan: Bu Tayyip Erdoğan değişmez [Erdogan: This Tayyip Erdogan will not change]. http://www.hurriyet.com.tr/gundem/23479966.asp, 12 June.

Hürriyet Daily News. 2013. Turkish PM Erdoğan reiterates his call for three children. http://www.hurriyetdailynews.com/turkish-pm-erdogan-reiterates-his-call-forthree-children.aspx?pageID $=238 \&$ nid $=38235$, 3 January.

Hürriyet Daily News. 2014. Turkish PM acknowledges phone call to media executive. http://www.hurriyetdailynews.com/turkish-pm-acknowledges-phone-call-to-mediaexecutive.aspx?pageID $=238 \& n I D=62368 \&$ NewsCatID $=338,12$ February.

Inalcik, Halil. 1992. Comments on sultanism: Max Weber's typification of the Ottoman polity. Princeton Papers in Near Eastern Studies 1: 1-14.

Internetmedya. 2017. Alişan: Cumhurbaşkanımız’a verdiğim sözü tuttum, http://www. internetmedya.com/alisan-cumhurbaskanimiza-verdigim-sozu-tuttum-7342h.htm, 22 April.

Kandiyoti, Deniz. 2014. No laughing matter: Women and the new populism in Turkey. https://www.opendemocracy.net/5050/deniz-kandiyoti/no-laughing-matterwomen-and-new-populism-in-turkey, 1 September.

Konak, Nahide and Rasim Özgür Dönmez. 2015. Deconstructing a neopatrimonial system via humor: Gezi park 'capulcu' protests in Turkey. In Waves of social movement mobilizations in the twenty-first century: Challenges to the neo-liberal world order and democracy, ed. Nahide Konak and Rasim Özgür Dönmez, 66-7. Lanham, MD: Lexington Books.

Konda. 2014. Konda Gezï report: Public perception of the 'Gezi protests.' Who were the people at Gezi Park? http://konda.com.tr/wp-content/uploads/2017/03/ KONDA_Gezi_Report.pdf, June 5.

Mardin, Serif. 1969. Power, civil society and culture in the Ottoman Empire. Comparative Studies in Society and History 11(3): 258-81.

McClintock, Anne. 1995. Imperial leather: Race, gender and sexuality in the colonial contest. New York: Routledge.

Mentan, Tatah. 2004. Dilemmas of weak states: Africa and transnational terrorism in the twenty-first century. Aldershot: Ashgate.

Millett, Kate. 2000[1970]. Sexual politics. Chicago, IL: University of Illinois Press.

Nilan, Pam and Argyo Demartoto. 2012. Patriarchal residues in Indonesia: Respect accorded senior men by junior men. European Journal of Social Sciences 31 (2): 279-93.

Ntvmsnbc. 2013. Erdoğan: Başörtülülere saldırdılar [Erdoğan: They attacked the headscarved]. http://www.ntvmsnbc.com/id/25448029/, 9 June.

Öniş, Ziya. 2004. Turgut Özal and his economic legacy: Turkish neo-liberalism in critical perspective. Middle Eastern Studies 40 (4): 113-34.

Özbudun, Ergun. 2000. Contemporary Turkish politics: Challenges to democratic consolidation. Boulder, CO: Lynne Rienner Publishers.

Pateman, Carole. 1988. The sexual contract. Stanford, CA: Stanford University Press.

Pierson, Christopher. 2011. The modern state. London: Routledge.

Pitcher, Anne, Mary H. Moran, and Michael Johnston. 2009. Rethinking patrimonialism and neopatrimonialism in Africa. African Studies Review 52 (1): 125-56. 
Radikal. 2014. Cumhurbaşkanı Erdoğan: Bu ülkede yıllarca doğum kontrolü ihaneti yaptılar [They have committed the treason of birth control in this country for years]. http://www.radikal.com.tr/turkiye/cumhurbaskani_erdogan_bu_ulkede_yil larca_dogum_kontrolu_ihaneti_yaptilar-1256542, 22 December.

Reporters without Borders. 2017. Journalism engulfed by the purge. https://rsf.org/en/ turkey.

Sabah. 7 November 2013. Gençleri Korumak Devletin Görevi [It is the state's duty to protect the youth]. http://www.sabah.com.tr/Gundem/2013/11/07/gencleri-koru mak-devletin-gorevi.

Sayar1, Sabri. 2011. Clientelism and patronage in Turkish politics and society. In The post-modern abyss and the new politics of Islam: Assabiyah revisited-Essays in honor of Serif Mardin, ed. F. Birtek and B. Toprak, 81-94. Istanbul: Bilgi University Press.

- 2014. Interdisciplinary approaches to political clientelism and patronage in Turkey. Turkish Studies 15(4): 655-70.

Schatzberg, Michael G. 1993. Power, legitimacy and "democratisation" in Africa. Africa: Journal of the International African Institute 63 (4): 445-61.

2001. Political legitimacy in Middle Africa: Father, family, food. Bloomington, IN: Indiana University Press.

Silverman, Reuben. 2014. Dogan versus Erdoğan: Business and politics in AKP-era Turkey. Mediterranean Quarterly 25(2): 131-51.

Sputniknews. 2016. Erdoğan: Çobanlı̆̆ın felsefesini anlamayan insan yönetemez, ben de bir çobanım. https://tr.sputniknews.com/ekonomi/201611141025797824-erdo gan-coban-insan-felsefe-coban/, 14 November.

Steinvorth, Daniel. 2012. Erdoğan the misogynist Turkish prime minister assaults women's rights. Der Spiegel. http://www.spiegel.de/international/europe/turkishprime-minister-erdogan-targets-women-s-rights-a-839568.html, 19 June.

Sunar, Ilkay. 1990. Populism and patronage: The Demokrat Party and its legacy in Turkey. Il Politico 55(4): 745-57.

Sydie, Rosalind. 1987. Natural women, cultured men: A feminist perspective on sociological theory. Toronto: Methuen.

The Economist. 2013. Alcohol in Turkey not so good for you. http://www.economist. com/news/europe/21578657-mildly-islamist-government-brings-tough-alcohol-re strictions-not-so-good-you, 1 June.

The Guardian. 2014. Turkish deputy prime minister says women should not laugh out loud. http://www.theguardian.com/world/2014/jul/29/turkish-minister-women-lau gh-loud-bulent-arinc, 29 July.

The Independent. 2012. "Abortions are like air strikes on civilians": Turkish PM Recep Tayyip Erdoğan's rant sparks women's rage. http://www.independent.co.uk/lifestyle/health-and-families/health-news/abortions-are-like-air-strikes-on-civiliansturkish-pm-recep-tayyip-erdogans-rant-sparks-womens-rage-7800939.html, 30 May.

Thomas, Gwynn. 2011. Contesting legitimacy in Chile: Familial ideals, citizenship, and political struggle, 1970-1990. University Park, PA: Penn State Press.

Thompson, Denise. 2001. Radical Feminism Today. London: Sage.

T24. 2013. Erdoğan: Gazeteci, sanatçı ve siyasetçiler kışkırttı, bu eylem derhal son bulmalı [Erdoğan: journalists, artists and politicians have provoked this: This has to stop immediately.] http://t24.com.tr/haber/erdogan,231470, 7 June. 
Walby, Sylvia. 1990. Theorizing patriarchy. Oxford: Blackwell.

Weber, Max. 1978. Economy and society. Berkeley, CA: University of California Press.

World Economic Forum. 2016. The global gender gap report 2016. http://reports.wefo rum.org/global-gender-gap-report-2016/rankings/.

Van de Walle, Nicolas. 2007. The path from neopatrimonialism: democracy and clientelism in Africa today. Cornell University Mario Einaudi Center for International Studies Working paper.

von Soest, Christian et al. 2011. How neopatrimonialism affects tax administration: A comparative study of three world regions. Third World Quarterly 32 (7): 1307-29.

Safak Yeni. 2017. Murat Yıldırım: Cumhurbaşkanımız benim manevi babam. http:// www.yenisafak.com/hayat/murat-yildirim-cumhurbaskanimiz-benim-manevibabam-2610805, 10 February.

Yesil, Bilge. 2014. Press censorship in Turkey: Networks of state power, commercial pressures, and self-censorship. Communication, Culture \& Critique 7: 154-73.

Yllmaz, Gözde. 2013. From the mainstream media to the alternative media: Media in Turkey and Taksim Gezi Park protests. Research Turkey 2(4): 17-9.

Yılmaz S,ener, M. 2016. Conditional cash transfers in Turkey: A case to reflect on the AKP's approach to gender and social policy. Research and Policy on Turkey 1(2): $164-178$. 